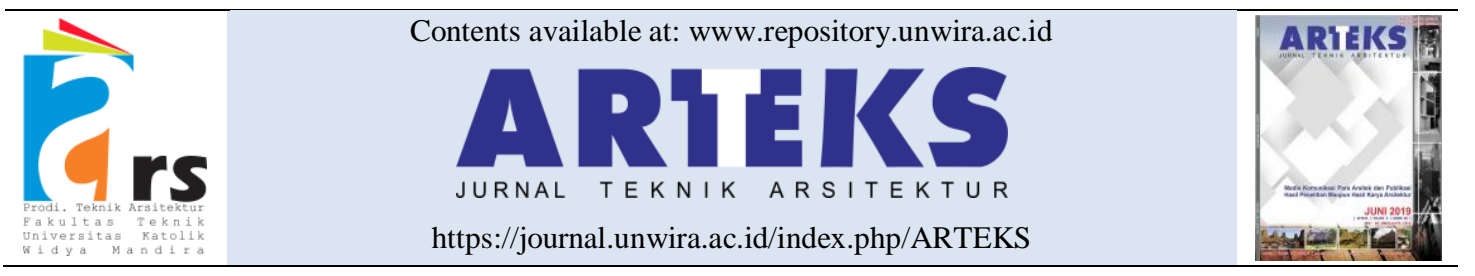

Research paper

doi: $10.30822 /$ arteks.v5i3.487

\title{
The hedonistic sustainability concept in the works of Bjarke Ingels
}

\section{Nita Dwi Estika ${ }^{1 *}$, Yudhistira Kusuma $^{2}$, Dewi Retno Prameswari ${ }^{3}$, Iwan Sudradjat ${ }^{1}$ (1)}

\author{
${ }^{1}$ History, Theory, and Criticism in Architecture Research Group, School of Architecture, \\ Planning, and Policy Development (SAPPD), Institut Teknologi Bandung, Jl. Ganesha, no. \\ 10, Bandung, Indonesia \\ 2 Architectural Planning Research Group, Department of Architectural Education, \\ Universitas Pendidikan Indonesia, Jl. Dr. Setiabudhi, no. 229, Bandung, Indonesia \\ ${ }^{3}$ School of Architecture, Planning, and Policy Development (SAPPD), Institut Teknologi \\ Bandung, Jl. Ganesha, no. 10, Bandung, Indonesia
}

\begin{tabular}{|c|c|}
\hline ARTICLE INFO & ABSTRACT \\
\hline $\begin{array}{l}\text { Article history: } \\
\text { Received April 29, } 2020 \\
\text { Received in revised form May 12, } 2020 \\
\text { Accepted July 26, } 2020 \\
\text { Available online December 01, } 2020\end{array}$ & \multirow{2}{*}{$\begin{array}{l}\text { Contemporary architects highlight past ideas and present new } \\
\text { manifestos often perceived as utopian. Bjarke Ingels introduced } \\
\text { hedonistic sustainability in response to the demand for } \\
\text { environmentally friendly and sustainable living through different } \\
\text { perspectives. This paper comprehensively explains the concept of } \\
\text { hedonistic sustainability through the designs of Bjarke Ingels, a } \\
\text { contemporary architect. Literature from various sources is examined } \\
\text { to describe Bjarke Ingels' idea. Hedonistic sustainability combines } \\
\text { sustainable ideas, fun, and community. Bjarke Ingels's architectural } \\
\text { design is applied through simulation and an ironic approach. Its } \\
\text { representation facilitates the exploration of the design objects } \\
\text { planned concretely. The idea of playful and communality was raised } \\
\text { through the design that accommodates various user activities. Bjarke } \\
\text { Ingels's idea is expected to contribute to the knowledge and } \\
\text { contemporary architecture design process in Indonesia. }\end{array}$} \\
\hline $\begin{array}{l}\text { *Corresponding author: Nita Dwi Estika } \\
\text { History, Theory, and Criticism in Architecture } \\
\text { Research Group, SAPPD, Institut Teknologi } \\
\text { Bandung, Indonesia } \\
\text { Email: nitaestika@ @ar.itb.ac.id } \\
\text { ORCID: 0000-0003-2117-482X }\end{array}$ & \\
\hline
\end{tabular}

\section{Introduction}

Architects become famous in other media because of their manifesto. A good manifesto combines a bit of terror, emotion, the prestige of capabilities, and utilizes rhetorical tools such as rhymes, word plays, and jokes. Jencks and Kropf (1997) grouped manifestos into five time periods, including, Post-Modern, Post-Modern Ecology, Traditional, Late Modern, and New Modern (Jencks 1997).

The appearance of Rem Koolhaas in 1994 with the manifesto of Bigness made him a new modern figure. The Manifesto Bigness represents what architecture can do at its maximum point. However, it is also a challenge since it may highlight the main weaknesses of the architecture (Jencks 1997). Rem Koolhaas, a founding partner of the OMA (Office for Metropolitan Architecture), was assisted by an apprentice named Bjarke Ingels in 1998. Manifesto Bigness Koolhaas inspired Ingels to be one of the innovative, ambitious, creative, and most famous contemporary architects of the younger generation. This success is also attributed to skills in using various platforms, including social media. Ingels won many awards because of the 
ability to produce innovative architectural works and international reputation (Sagdic 2016).

Bjarke Ingels founded the Bjarke Ingels Group (BIG) in 2005, which is known by the manifesto Yes is More, a theory of evolution (Bjarke Ingels Group 2009). This manifesto was founded on the abstraction from the thoughts of naturalist Charles Darwin and philosophers Friederich Nietzsche (Møller 2013). "Yes is More" by Ingels was juxtaposed with six other legendary architectural manifestos, including Vitruvius, Le Corbusier, Steen Eiler Rasmussen, Aldo Rossi, Roberto Venturi, and Rem Koolhaas (Arcspace 2014). Stable manifestos can become a theory, which is a discourse that explains the practice of architectural production along with a description of its challenges (Jencks 1997; Nesbitt 1996). The manifestos stated by architects can be categorized into groups of theories to form the architecture theory (Sudradjat 1997). The theory represents how architects develop and use principles, knowledge, techniques, and other resources in the design process (Sudradjat 2020). It underlines the background of the architect's design process, such as the use of media and ways of acting, enriching historical and cultural diversity (Widodo 2019; Subroto 2019).

Through the Yes Is More manifesto, Ingels synthesized various concepts, including Hedonistic Sustainability. This paper explains Hedonistic Sustainability's design concept, ranging from the origin, principles, implementation, and context of application through the architectural works of Bjarke Ingels. The purpose of choosing this concept was to appreciate the BIG for its exciting design philosophy and challenging the idea of sustainable living principles. This concept is also a contextual idea with the urgency of today's architectural design that must prioritize environmentally friendly principles.

\section{Method}

This study uses a qualitative descriptive approach, commonly used to build knowledge patterns based on constructive perspectives sourced from individual experience and historical values (Creswell 2014). Data collection involved literature studies of various sources, including books, articles, and information from the official website of Bjarke Ingels's works. Text data processing methods were used to extract text from various sources. Furthermore, content analysis techniques were used to determine the inference of the selected work to provide an overview of the interpretation of ideas or hedonistic sustainability concepts proposed by Bjarke Ingels (Krippendorff 2012). The essence was responded to by associating this thought with a broader case to make a more general and comprehensive conclusion on the hedonistic sustainability concept.

\section{Result and discussion}

The Ingels architecture process with Koolhaas provides show that each project is handled uniquely based on specific conditions. Projects start with a story attached to a city, about art and technology, and the institutions that develop. Therefore, Ingels concludes that architecture is part of society and is based on societal issues (Parker 2012).

"Yes is More" might be perceived as a joke from a famous quote by the founding father of the modern revolution Mies Van Der Rohe, "Less is More." However, the choice of phrases has a solid basis. Apart from the concrete form of the Less is More spell, which results in the repetition of identical square buildings dominating, "Yes is More" also refers to the fact that the architecture development is a contradiction and revolution of previous ideas. Ingels intended to free architecture from traced cliches and viewed modern life as an inspiring challenge. As an architect in the 21 st century, he shows that the project's importance is not formulated under the basic guidelines and principles of architecture, but is focused on concept research on architectural projects expected to be the best in the market.

According to Ingels, the need in architecture today is not revolution, but evolution. Architecture should adapt progressively to the development of life. It should follow the way of life, rather than slowing the progression of life by adjusting to obsolete ideas from the past. Perfect architecture should say "yes!" to every desire and need (Bjarke Ingels Group 2009).

"Yes is more" represents Ingels's optimism as a designer in the contemporary era to produce perfect architectural works. Instead of positioning themselves toward "pragmatics" that kill the wild ideas of an architect or "utopians" that reject 
various realities, Ingels merge the two poles in an architectural design entitled "pragmaticutopianism" (Bjarke Ingels Group 2009). Through the Pragmatic Utopianism idea, he was confident and optimistic that architectural works should not be partial. Architectural work should reach both sides through the creativity of an architect and produce outcomes that accommodate various needs.

"How could the ecosystem live sustainably when humans continue to do what they want?" (Fiore, Phillips, and

Sellers 2014).

The Hedonistic Sustainability concept also emanated from the foundation of pragmatic utopianism. The hedonistic preposition seems to contradict with the main idea, which is sustainability. This concept can be expressed using the term "extravagant while saving." This concept is against sustainability, which denotes that living sustainably is a sacrifice (investment) for the greater good (Fiore, Phillips, and Sellers 2014). Ingels and BIG are active in defining urban scenarios, bringing concepts related to society, economy, and ecology to create synergies between sustainability, community needs, and spectacular design. (BIG - Bjarke Ingels Group 2018; Bjarke Ingels Group 2018).

\section{Bjarke Ingels's thoughts: Hedonistic sustainability}

Architectures are artistic three-dimensional, and ecosystem designs that unite ecological and economic systems. Architects should integrate everything resourcefully in a plan and ensure the flow of resources is sustainable (Ingels 2012). When ecology and economics are combined, people tend to focus on the boundaries that emerge as rules, eliminating the community values built in architecture. According to Ingels, this is a challenge to determine new ways of building a pro-community ecological and economic system (Bjarke Ingels Group 2009).

There is a general misconception of sustainability regarding how much the community's life quality should be sacrificed to achieve sustainability (Ingels 2012). This is the underlying concept of hedonistic sustainability. According to Ingels, the solution to the conflict is purely a matter of design.

"Sustainability cannot be like a moral sacrifice or political dilemma or a philanthropic cause. It has to be a design challenge." (Sanders and Sanders 2019;

Ingels 2012).

Hedonistic sustainability is a vision to respond to current challenges in line with the need for new ways of addressing the evolving contemporary lives, multicultural issues, economic problems, and technological and communication developments. Hedonistic sustainability is a mind-set that integrates aspects of sustainability with playfulness into a building to improve human life.

Ingels doubt that the environment is currently undergoing an ecological regression (Bjarke Ingels Group 2009). In his view, the environment is ecologically "possible" in progress. The statement seems to show the quality of the built environment whose development is not proportional to the needs and lifestyles of humans currently. This situation indirectly forces humans to adjust their lifestyles for sustainability.

As an architect with authority and responsibility to change the built environment for the better, Ingels stated that an architect should create a sustainable design and still accommodate the way humans want to live, rather than precisely imposing limits on their life (Bjarke Ingels Group 2009). Ingels change the sustainable paradigm that cramps the society because it has to limit everything. A sustainable life is not merely about changing existing lifestyles, and the world can be changed to suit human life.

Ingels developed the idea of a pro-community built environment design in which expending energy produced more of it (Bjarke Ingels Group 2009). Therefore, the Hedonistic Sustainability concept is needed. In his book Yes is More, Ingels criticized some of the contents of "Ten Commandments of Good Consumption," as shown in table 1.

Table 1. Hedonistic sustainability critiscism of ten commandments of good consumption

\begin{tabular}{ll}
\hline $\begin{array}{l}\text { Ten commandments of } \\
\text { good consumption }\end{array}$ & Hedonistic sustainability \\
\hline Reduce, reuse, recycle & Use, reuse, recycle \\
\hline Stay close to home & Hit the road \\
\hline $\begin{array}{l}\text { Minimize the use of } \\
\text { combustion engines }\end{array}$ & $\begin{array}{l}\text { Maximize the use of } \\
\text { hydrogen engines }\end{array}$ \\
\hline $\begin{array}{l}\text { Reduce fuel } \\
\text { consumption }\end{array}$ & Produce energy while driving \\
\hline $\begin{array}{l}\text { Support government } \\
\text { regulation with political } \\
\text { choices }\end{array}$ & $\begin{array}{l}\text { Support youth own } \\
\text { household with energy }\end{array}$ \\
\hline $\begin{array}{l}\text { Support thoughtful } \\
\text { innovation }\end{array}$ & (agree) \\
\hline
\end{tabular}




\begin{tabular}{ll}
\hline $\begin{array}{l}\text { Ten commandments of } \\
\text { good consumption }\end{array}$ & Hedonistic sustainability \\
\hline Prioritize & $\begin{array}{l}\text { The more you use, the more } \\
\text { you get }\end{array}$ \\
\hline Vote & Waste \\
\hline Do not feel guilty & (agree) \\
\hline Enjoy what you have & Enjoy more \\
\hline
\end{tabular}

Source: (Bjarke Ingels Group 2009)

Through the hedonistic sustainability concept, Ingels offers expectations and beliefs that humans can live in a utopian architecture world that is beautiful but still be responsible. Sustainable design provides fun and enthusiasm and can improve the quality of life for individuals and communities (Fiore, Phillips, and Sellers 2014). However, to create a pleasant sustainable environment, public and community participation in the design process is needed (Fiore, Phillips, and Sellers 2014).

"... to look at some different

approaches where sustainable cities and

buildings increase the quality of life"

(Ren 2016).

Hedonistic sustainability, as the design principle of BIG in various articles, is considered closer to the joke in architecture. Szczegielniak (2015) explained that BIG is an expert in making jokes in architecture with a funny design process. However, it is a solution to problems in various contexts faced by the development of Ingels architecture. With this approach, they expect architecture to be readily accepted and understood by the wider community, attracting society's involvement in its architectural work.

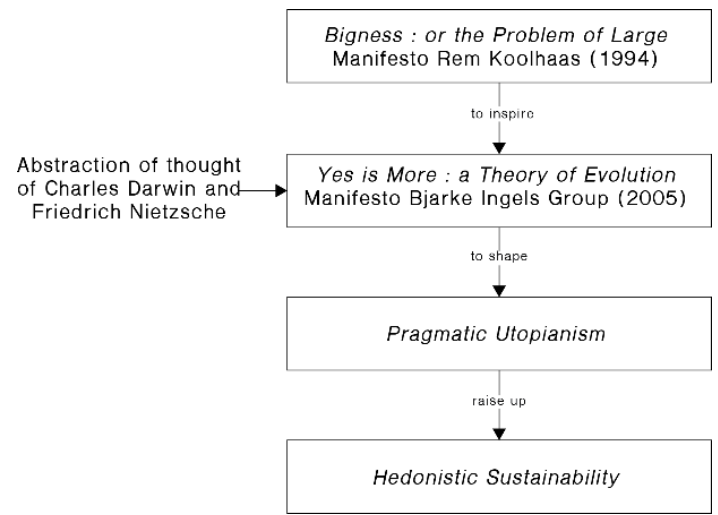

Figure 1. Schema of hedonistic sustainability concept

\section{Design approach}

In the design process, Ingels uses two approaches to achieve optimal design: simulation and irony. Specifically, this was meant to achieve a synergistic and sustainable design.

The simulation approach is analogous as a boy playing with a Lego model or a digital computer game. Many Ingels buildings oppose the conventions and dimensions of traditional architecture and highly eccentric and photogenic. Ingels uses the camouflage perspective learned from Koolhaas and used digital technology to formulate influential designs (Sagdic 2016). For instance, the use of simulation, imitation, and representation by BIG was applied to The Mountain project (2007) in Copenhagen. The project explores the experience (simulation) of life on the "mountain," and therefore, an artificial mountain was built. It is a view of new mountainous settlements in the sub-urban area of Copenhagen (Ingels 2012). Simulation is a representation of reality that is considered equal because it produces several authentic characteristics. In this project, reproduced "mountains" emerge as imaginative theatrical realities (Balık and Allmer 2015a).

The ironic approach is also used as a design to create an ironic expression and form a more iconic building. An ironic expression on Ingels architecture is a design input that develops pragmatic-utopian design ideas, such as rational and irrational binary, usual and unusual, or serious and funny. Ingels developed irony as a collective creation tool to produce ideas with other architects.

For example, in The Mountain project (Figure 2), Ingels deliberately made the residential block "The Mountain" look like a mountainous settlement. In reality, the Copenhagen plain is a flat without mountains. The irony approach arises because the resulting design contradicted the situation in Copenhagen.

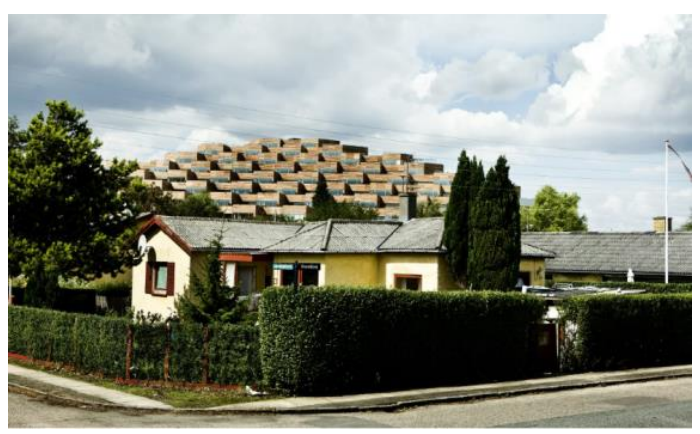

Figure 2. The mountain building Source: (Bjarke Ingels Group 2007) 
The design decision is not merely the fulfillment of utopian desire. There are sustainability values accommodated in The Mountain's design, including land reduction (building function integration), natural lighting and ventilation, the view of each occupancy, and sustainable technology (Bjarke Ingels Group 2007).

\section{Implementation of the hedonistic sustainability concept in Bjarke Ingels' work}

The Hedonistic Sustainability concept is widely applied to projects directed by Ingels and BIG. The explanation of this concept's implementation is based on the analysis using two Ingels design approaches, including a simulation (SA), and an ironic approach (IA). Several iconic projects by Ingels withthe Hedonistic Sustainability concept are briefly explained in table 2.

Table 2. Implementation of hedonistic sustainability concepts in Several BIG Projects

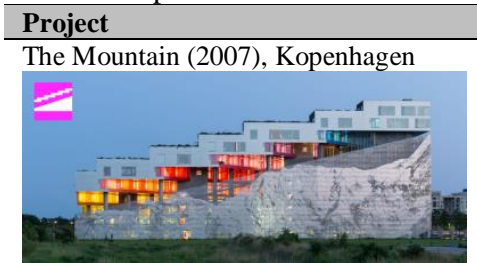

https://big.dk/\#projects-mtn

\section{Design approach}

- $S A$ : The parking building is likened to a mountain, and then dwelling is placed on it (the experience of settlement life on the mountain).

- IA: Design residential blocks like in the mountains, while Copenhagen is a city without mountains.
Hedonistic sustainability value

- Hedonistic: The pleasure of living in the mountains; Sub-urban life in urban density.

- Sustainability: Integration of two building functions; Natural lighting, fresh air, views, and parking in each residential unit; Roof garden with irrigation from rainwater collection technology.

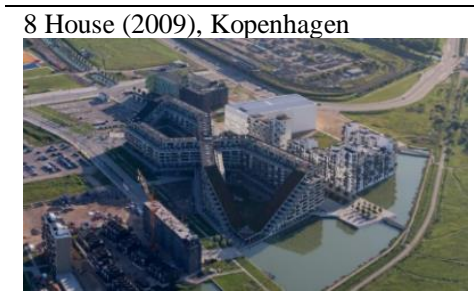

https://big.dk/\#projects-8
- SA: The experience of normative residential life (horizontal land) such as on a city roadside with bicycle and pedestrian paths to access various facilities.

- IA: Transform the idea into vertical residential typologies on confined land.
- Hedonistic: Horizontal residential life inside a vertical housing (pedestrian path for walking and biking).

- Sustainability: Integration of various facilities in one residential block area; Roof garden to reduce the effects of urban heat island; rainwater collection technology.

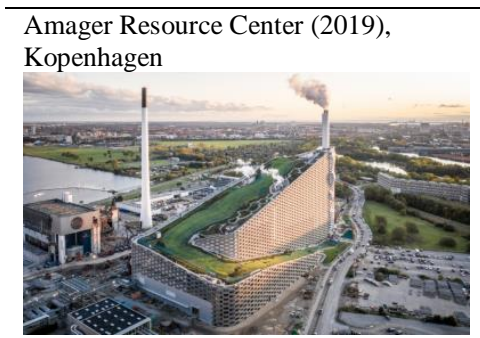

- $S A$ : Making the incinerator facility community-friendly (obscuring the image of industrial buildings); Making "mountains" for recreation Copenhagen community.

- IA: Mountain recreation in an area without mountains; Recreation on top of industrial facilities (incinerator).
- Hedonistic: Mountain recreation (ice skating, hiking, wall climbing).

- Sustainability: Turn obsolete incinerator into a green building landmark; Educational facilities about sustainability for the community (waste-to-energy plant); large roof garden for new natural ecosystems; New recreation area.

https://big.dk/\#projects-arc

Source: (Bjarke Ingels Group 2020; Støa 2008; Balık and Allmer 2015b; Vyzoviti 2013; Ingels 2012)

Many Ingels architectural works that apply similar design patterns, include Copenhagen Harbor Bath (2005) in Copenhagen, Danish Pavilion (2010) in Shanghai, and VIA 57 West (2016) in New York. The idea of these works was to mergepleasure into a sustainable environment system. It relieves the burden of boundaries arising from sustainable principles. Ingels created an environmental nuance that makes ordinary people interested and willing to understand sustainable living and living. In this case, the critical thing is the design following the desires and ways of life of the community, sourced from the societal stories, and adding pleasure (playfulness) in the design.

The Hedonistic Sustainability concept is a contemporary thought that can be used in architectural design. It is in line with the urgency of the current design that should meet the standards of green architecture and sustainable development. Therefore, the assertion that the quality of sustainable physical design needs to be supported by the involvement of the surrounding community is disputed. Ingels, in his design, has 
successfully integrated both aspects. Through creativity as an architect, an unusual way to make the community to live with sustainable principles was discovered.

Sustainable architectural design approaches may vary with the context. Ingels' hedonistic sustainability concept widely applied in the Scandinavian region can be successful since it is ready in various aspects. In other regions, architects must be very creative in finding solutions to the spirit of sustainable communitybased design. Contextuality is very important since designing a built environment improves the quality of life of its users based on their needs. A well-designed and sustainable built environment persuades users to be indirectly integrated into it.

\section{Conclusion}

"Yes is More" as a typical manifesto by Bjarke Ingels elucidates pragmatic-utopianism, an understanding of reaching two opposing poles. Pragmatic-utopianism opens the awareness that radical evolution is a necessary attitude and spirit in various fields, including architecture, not merely a revolution. The changing human life demands the fulfillment of various needs. This means that architecture should follow the development and way of life of the community.

Hedonistic Sustainability works through the integration of sustainability and fun aspects. The design process by Ingels and BIG often combine functions that appear to have no synergy. This is because the "ironic" approach to the hedonistic sustainability concept proposed by Ingels trigger designs that seem out of the box, demanding innovation in each design. The representation of a particular object in each Ingels design enriches the design concept. This is carried out by representing natural formations and urban conditions. The representation of an object is adapted into formations and elements attached to each design, believing that each user feels the presence of the object.

To present a playful impression on each design, Ingels present attractions for users. According to Ingels, every user in the design can move dynamically. This means each design is supported by public facilities that trigger motor users. The impression of playfulness in Ingels's work is also reflected in its mass formation. The building elements are arranged by playing horizontal, vertical, and diagonal axes. Therefore, repetition back and forth, rise-and-sink, as well as up and down in the design, produces a building mass with a dynamic impression.

Ingels responds to the surrounding environment to bring up sustainability aspects of each design. He uses every field in building works to respond to the surrounding climate and conditions. The green elements on the roofs and walls of buildings maintain and enhance green open spaces in the city where the building stands. The use of materials responding to the environment optimizes design performance. This is one of Ingels's efforts to harmonize work with the surrounding environment.

\section{References}

Arcspace. 2014. '7 Must-Read Architectural Manifestos'. $\quad$ Archspace. 2014. https://arcspace.com/article/7-must-readarchitectural-manifestos/.

Balık, Deniz, and Açalya Allmer. 2015a. 'This Is Not a Mountain!: Simulation, Imitation, and Representation in the Mountain Dwellings Project, Copenhagen'. Architectural Research Quarterly $19 \quad$ (1): 30-40. https://doi.org/10.1017/S1359135515000196.

—. 2015b. 'A "Big" Yes to Superficiality: Arlanda Hotel by Bjarke Ingels Group'. METU JOURNAL OF THE FACULTY OF ARCHITECTURE $\quad 32$ (01). https://doi.org/10.4305/METU.JFA.2015.1.1 0.

BIG - Bjarke Ingels Group. 2018. 'BIG Bjarke Ingels Group Designs a Restaurant Village'. Floornature: Architecture \& Surfaces. 2018. https://www.floornature.com/big-bjarkeingels-group-designs-restaurant-village14172/\#.

Bjarke Ingels Group. 2007. 'MTN - The Mountain'. 2007.

- 2009. Yes Is More: An Archicomic on Architectural Evolution. Cologne, Germany: TASCHEN.

- 2018. The Spectacular and Sustainable Scandinavian Architect. Cologne, Germany: TASCHEN.

- 2020. 'BIG - Project'. 2020.

Creswell, John W. 2014. Research Design: Qualitative, Quantitative and Mixed Methods 
Approaches. 4th ed. California: SAGE Publications.

Fiore, Stephen M., Elizabeth Phillips, and Brittany C. Sellers. 2014. 'A Transdisciplinary Perspective on Hedonomic Sustainability Design'. Ergonomics in Design: The Quarterly of Human Factors Applications $\quad 22 \quad$ (2): 22-29. https://doi.org/10.1177/1064804613516762.

Ingels, Bjarke. 2012. Hedonistic Sustainability. Stockholm, Sweden: KTH Royal Institute of Technology.

Jencks, Charles. 1997. Theories and Manifestoes of Contemporary Architecture. Edited by Karl Kropf. London: Academy Press.

Krippendorff, Klaus. 2012. Content Analysis: An Introduction to Its Methodology. Third. London: SAGE Publications, Inc.

Møller, Anders. 2013. 'Yes Is More: The BIG Philosophy'. ArchDailey. 2013. https://www.archdaily.com/366660/yes-ismore-the-big-philosophy.

Nesbitt, Kate. 1996. Theorizing a New Agenda for Architecture:: An Anthology of Architectural Theory 1965 - 1995. New York: Princeton Architectural Press.

Parker, Ian. 2012. 'High Rise - A Bold Danish Architect Charms His Way to the Top'. The New Yorker. 2012. https://www.newyorker.com/magazine/2012/ 09/10/high-rise.

Ren, Carina. 2016. 'Cool or Hot Greenland? Exhibiting and Enacting Sustainable Arctic Futures'. Journal of Cleaner Production 111 (January):

442-50. https://doi.org/10.1016/j.jclepro.2014.12.024.

Sagdic, Zafer. 2016. 'The 21st Century Architecture: Searching of the Concept'. MEGARON / Yildız Technical University, Faculty of Architecture E-Journal 11 (1): 179-86. https://doi.org/10.5505/megaron.2016.93064.

Sanders, Mark Callis, and Charlotta E. Sanders. 2019. 'A World's Dilemma "upon Which the
Sun Never Sets": The Nuclear Waste Management Strategy (Part II): Russia, Asia and the Southern Hemisphere'. Progress in Nuclear Energy 110 (January): 148-69. https://doi.org/10.1016/j.pnucene.2018.09.00 9.

Støa, Eli. 2008. 'Urban Cottages - Rural Homes? Challenges towards a More Sustainable Residential Culture and the Role of Architecture'. Nordic Journal of Architectural Research 20 (3): 59-72.

Subroto, T. Yoyok Wahyu. 2019. 'Koeksistensi Alam Dan Budaya Dalam Arsitektur'. ARTEKS : Jurnal Teknik Arsitektur 3 (2): 5-8. https://doi.org/10.30822/artk.v3i2.244.

Sudradjat, Iwan. 1997. 'Membangun Sistem Teori Arsitektur Nusantara: Mengubah AnganAngan Menjadi Kenyataan'. In Simposium Nasional Teori Arsitektur: "Menyikapi Alih Abad Mепијu Milenium Baru Arsitektur Nusantara. Bandung: Jurusan Arsitektur, Fakultas Teknik, Universitas Katolik Parahyangan.

- 2020. 'Teori Dalam Penelitian Arsitektur'. ARTEKS: Jurnal Teknik Arsitektur $\quad 5 \quad$ (1): 1-5. https://doi.org/10.30822/arteks.v5i1.378.

Vyzoviti, Sophia. 2013. 'Virtual Landforms:Representations of Performative Actions Augmenting the Urban Realmthrough Spontaneous Appropriations of Found Spaces'. In "Changing Cities":Spatial, Morphological, Formal \& Socio-Economic Dimensions, 575-79. Skiathos island, Greece. https://www.academia.edu/4227686/Virtual_1 andforms_Representations_of_performative_ actions_augmenting_the_urban_realm_throu gh_spontaneous_appropriations_of_found_sp aces.

Widodo, Johannes. 2019. 'Human, Nature, And Architecture'. ARTEKS: Jurnal Teknik $\begin{array}{llll}\text { Arsitektur } \quad 3 & \text { (2): } 145-48 .\end{array}$ https://doi.org/10.30822/arteks.v3i2.65. 
ARTEKS : Jurnal Teknik Arsitektur, Volume 5, Issue 3, December 2020

pISSN 2541-0598; eISSN 2541-1217 